\title{
Soybean: Friend or Foe
}

\author{
Cristina M. Sena and Raquel M. Seiça \\ Institute of Physiology; IBILI, Faculty of Medicine, University of Coimbra \\ Portugal
}

\section{Introduction}

Soy products have been consumed in Asian countries such as China and Japan for many centuries. Epidemiological studies have shown a lower incidence of several chronic diseases in Asia when compared to Western countries, including cardiovascular diseases and certain types of cancer (Wu et al., 1998; Messina, 1995). These studies have suggested that consumption of a traditional Asian diet high in soy may play a pivotal role in preventing chronic diseases.

In 1999, the Food and Drug Administration (FDA) in USA approved a health claim based on the role of soybean protein in reducing the risk of coronary disease. This claim establishes that soybean protein included in a diet low in saturated fat and cholesterol may reduce the risk of coronary disease (FDA, 1999; Henkel, 2000).

Soybeans (Glycine max) are a species of legume that yields a valuable amount of oil that has a healthy fatty acid profile and high-quality protein that is replete in all the essential amino acids required for sustaining human nourishment (Young, 1991). Soybeans have antihypertensive, anticholesterol, and antioxidant activities, and appear to prevent several types of cancer (Wu et al., 1998; Messina, 1995). However, other studies suggest that soy is linked to health problems. Thus, soy products are best consumed in moderation to obtain the benefits they offer without any of the potential negative consequences.

\subsection{Composition}

Soybean products have been designated as one of world's healthiest foods due to being an excellent source of high quality protein as well as providing various health benefits. Soybean contains vegetable protein, oligosaccharides, dietary fiber, phytochemicals (especially isoflavones), and minerals (Anderson et al., 1999; Messina, 1999; Liu, 1999) (table I, Fig 1). The association of high-quality protein and phytochemicals, especially isoflavones (genistein and daidzein), is unique among plant-based proteins because isoflavones are not widely distributed in plants other than legumes (Velasquez \& Bhathena, 2007).

In addition, large amounts of secondary metabolites are also present in both seeds and leaves of soybean: for example, it has been reported that soybean leaves normally accumulate high levels of several secondary metabolites, including kaempferol and quercetin (Buttery \& Buzzell, 1975). The beans also contain significant amounts of phytic acid (Garcia et al., 1997).

Soybean products have low levels of saturated fat (Friedman \& Brandon, 2001). The lipid content of soybean is approximately $60 \%$ polyunsaturated, $24 \%$ monounsaturated (MFA) 
and 15\% saturated (SFA). Soybean fat stands out for its high content of the polyunsaturated fatty acids, linoleic (C18: 2) and linolenic (C18: 3) acids, both of which are essential fatty acids (Anderson et al., 1999; Garcia et al., 1997). Soybean offers one of the few non-fish sources rich in omega-3 fatty acids, essential for various body functions. Available data suggest that soybean could be a good source to increase the linolenic acid intake in people with a poor $\omega-3$ fatty acids diet.

The protein content of soybean is $32 \%$ to $42 \%$ (depending on the variety and growth conditions) of which approximately $80 \%$ is composed of 2 storage globulins, 7S globulin ( $\beta$ conglycinin) and 11S globulin (glycinin), having various functional and physicochemical properties (Garcia et al., 1997; Kwon et al., 2002; Kwon et al., 2003). Soybean products are considered a good substitute for animal protein, and their nutritional value is almost equivalent to that of animal protein because soy proteins contain most of the essential amino acids for human nutrition.

Soybeans cannot be eaten raw; the heat-labile antinutrients (e.g. trypsin and chymotrypsin inhibitors) must undergo effective thermal inactivation to improve soy's digestibility and its sulfur amino availability in humans (Damodaran, 1996). Traditional methods of preparing soybeans for consumption include germination, cooking, roasting, and fermenting. Soy can be used as alternative to a variety of dairy and meat products. People who are intolerant of lactose can eat imitation dairy products. Along with providing alternative options of certain foods, soy protein and isoflavones are thought to have many health benefits.

\begin{tabular}{ll}
\hline Composition & Soybean seeds \\
\hline Complex carbohydrates (g) & 21 \\
Simple carbohydrates (g) & 9 \\
Water (g) & 8.5 \\
Vitamin C (mg) & 6 \\
Niacin (mg) & 1,6 \\
Choline (mg) & 115.9 \\
Vitamin E (mg) & 0.85 \\
Protein (g) & 36 \\
Total fat (g) & 19 \\
Saturated fat (g) & 2.8 \\
Monounsaturated fat (g) & 4.4 \\
Polyunsaturated fat (g) & 11.2 \\
Phytosterols (mg) & 161 \\
Fiber, total dietary (g) & 9.3 \\
Calcium (mg) & 276 \\
Magnesium (mg) & 280 \\
Potassium (mg) & 1.797 \\
Iron (mg) & 16 \\
Zinc (mg) & 4.8 \\
\hline
\end{tabular}

Table 1. Nutrition profile of soybeans expressed per 100g Dry Matter. Data extracted from the USDA National Nutrient Database for Standard reference (USDA, 2009).

Isoflavones and soy proteins are the two major groups of components that have received the most attention (Xiao, 2008; Friedman \& Brandon, 2001; Omoni, 2005). Isoflavones belong to a broad group of plant derived compounds that have structural and functional similarities to 
estrogens, and this has led to the term phytoestrogens (Setchell, 1998). The analysis, bioavailability, and health effects of isoflavones have been extensively studied and frequently reviewed (Cassidy et al., 2006; Larkin et al., 2008). Consumption of isoflavones has been suggested to have multiple beneficial effects on certain types of cancer (Adlercreutz, 2002; Gullett et al., 2010; Sarkar, 2003), bone functions (Zhang et al., 2008), and prevention of obesity (Orgaard, 2008; Velasquez \& Bhathena, 2007). Soy protein has also been shown to have several beneficial effects, including cardiovascular and others related to obesity and renal functions (Velasquez \& Bhathena, 2007; Anderson et al., 1999; Anderson, 2008).

Several studies suggest that soybean products seem to have a positive effect on lipids (Anderson et al., 1995), diabetes (Chandalia et al., 2000), diarrhoea and constipation and as a therapy of irritable bowel syndrome (Bosaeus, 2004); they have also anti- inflammatory and anti-carcinogenic effects on digestive system (Scheppach et al., 2004). Thus, we will focus at describing some of the beneficial effects of soybean products and discuss some controversies.

Bioactives: lectins, lipoxygenases, $\beta$ amylase, etc...

Secondary metabolites: saponins, phytic acid, isoflavones, etc...

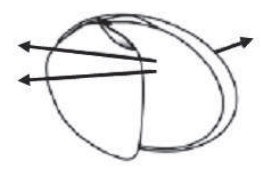

Soy hulls (seed coats) contain fiber used in bran, breads, cereal and snacks

Carbohydrate $=30.2 \%$

$\sim 50 \%$ soluble

$\sim 50 \%$ insoluble
Protein $=36.5 \%$

Contains all 8 essential amino acids

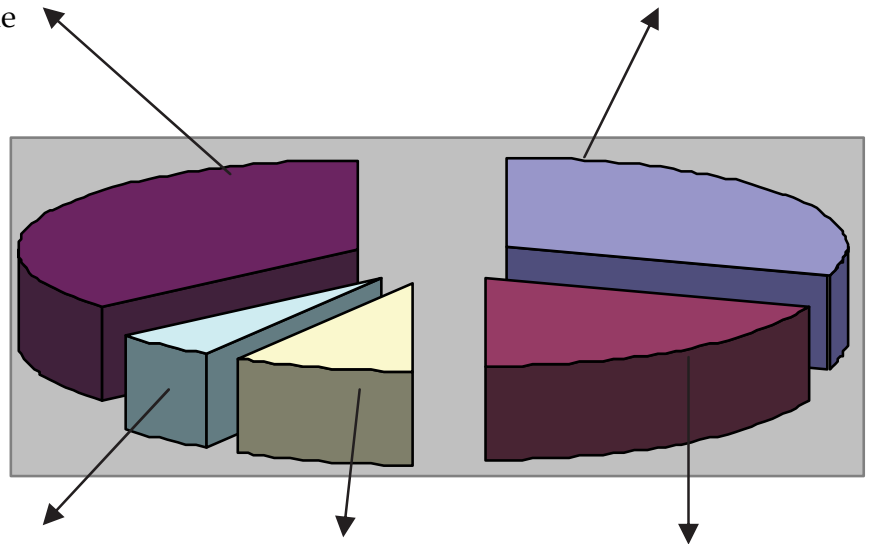

Ash $=4.9 \%$

Fiber $=9 \%$

Fats $=19.9 \%$

$\mathrm{g} / 100 \mathrm{~g}$

SFA

MFA

PUFA

Cholesterol

0

Fig. 1. The percentage nutrient composition of whole soy. Soybean seeds consist of approximately $36 \%$ protein, $30 \%$ carbohydrate, $20 \%$ fat, $9 \%$ crude fiber, and $5 \%$ ash (Garcia et al., 1997). Data extracted from the USDA National Nutrient Database for Standard reference (USDA, 2009). 


\section{Beneficial effects of soy products}

\subsection{Lowering cholesterol/reducing heart disease}

The atheroprotective effects of soy-based diets have been attributed to its effect on reducing serum cholesterol levels in animal and human nutrition studies (Anthony et al., 1997; Jenkins et al., 2002; Reynolds et al., 2006). Although, other studies reveal that soybeans have also atheroprotective effects independent of the lipid-lowering activity (Ni et al., 1998; Adams et al., 2002; Nagarajan et al., 2008).

Eating soy protein in particular, has been shown to reduce levels of both cholesterol and blood lipids (Anderson et al., 1995). Extensive clinical and experimental evidence links hypertension and atherosclerotic vascular disease with the accumulation of oxidized LDL and the enhanced generation of reactive oxygen species within the vascular walls (Stocker \& Keaney, 2004). We have previously described that soybean oil decreased plasma levels of cholesterol (total and non-HDL) and triglycerides in an aged animal model of type 2 diabetes with hyperlipidemia (Sena et al., 2008a). Thus, the lipid-lowering properties of soy products are very important in this context. Moreover, recent studies in the atherosclerosissusceptible apolipoprotein E knockout mouse models showed that atherosclerotic lesions are reduced when fed a soy-containing diet despite unchanged serum lipid levels (Ni et al., 1998; Adams et al., 2002; Nagarajan et al., 2008). These studies suggest that dietary soy may inhibit atherosclerotic lesion development by mechanism(s) other than lowering serum lipid levels. Furthermore, other studies have demonstrated that mice fed the $\beta$-conglycinincontaining diet, had a pronounced inhibitory effect on the development of atherosclerosis compared to mice fed casein-lactalbumin-based diets (Adams et al., 2002; Adams et al., 2004). These findings suggest an atheroprotective role for the protein components of soy diet or peptides generated from soy protein such as $\beta$-conglycinin and glycinin.

Although not completely elucidated there are several components in the soy that have atheroprotective properties. Several studies suggest that soybean dietary fiber also plays a role in the reduction of cholesterol levels in some hyperlipidemic individuals and has a major protective effect on cardiovascular disease (Anderson et al., 1995; Anderson et al., 1999; Reynolds et al., 2006).

The protective effect of soy protein has been investigated in many clinical trials. Several meta-analyses show that the intake of soy protein could lead to a significant mean reduction in serum LDL (Anderson et al., 1995; Reynolds et al., 2006; Weggemans \& Trautwein, 2003; Zhan \& Ho, 2005; Balk et al., 2005). A significant reduction in triglyceride was also found in two of the studies (Anderson et al., 1995; Balk et al., 2005). Overall, these meta-analyses of individual clinical trials concluded a beneficial effect on serum cholesterol level through the consumption of 25-50 g of soy protein daily (Anderson et al., 1995; Reynolds et al., 2006; Weggemans \& Trautwein, 2003; Zhan \& Ho, 2005; Balk et al., 2005).

Replacing saturated fat by polyunsaturated fat as the main source of dietary fat intake is effective in reducing serum LDL and preventing atherosclerosis (Rudel et al., 1995; Mensink et al., 1992). A meta-analysis of 60 clinical trials further concluded that polyunsaturated fat from soy oil could increase the concentration of HDL-cholesterol, which is important for cardiovascular health (Mensink et al., 2003).

One randomized, controlled clinical trial found significant reductions in both systolic and diastolic blood pressure for those consuming $40 \mathrm{~g}$ of soy protein supplement daily after 12 weeks, when compared with control subjects who received complex carbohydrate (He et al., 2005). The study provided valuable evidence of soy protein as a substitute for carbohydrate, but long-term studies are required to confirm its beneficial effects. 
Consumption of isoflavones has also been suggested to have multiple beneficial effects on heart disease (Clair \& Anthony, 2005; Clarkson, 2002). Soya products contain significant amounts of the isoflavones genistein and daidzein either in an unconjugated aglycone form or in different glycoside conjugates (Setchell, 1998; Williamson \& Manach, 2005). Although there is controversy concerning the benefits of soy isoflavones (Sacks et al., 2006a), it is clear that isoflavones can modulate vascular reactivity and have important anti-inflammatory roles via the activation of estrogen receptors and/or intracellular kinase signalling cascades (Li et al., 2006). The gender specific bioavailability data of isoflavones and its metabolites is very important to formulate food composition/ matrix characteristic of soy-based functional foods. A randomised crossover human trial has examined the effect of age, gender, and influence of the food matrix on the bioavailability of different soy foods (Cassidy et al., 2006), but more convincing human studies are required to make a definite health claim.

A clinical trial evaluating the benefits of soy isoflavones reported increased brachial artery flow-mediated dilation (Squadrito et al., 2003). Clarkson (2002) reported plasma concentrations of genistein and daidzein that range between 50 and $800 \mathrm{ng} / \mathrm{mL}$ in adults consuming soy-rich foods, similar to levels found in the Japanese population.

Several human studies during last years are not in agreement with the beneficial effect of soy isoflavones (Sacks et al., 2006b), rather the evidence favours soy protein. However, the American Heart Association Nutrition Committee has not ruled out the possibility that another component could be the active factor (Sacks et al., 2006b).

Discrepancies among clinical studies examining cardiovascular benefits of isoflavones may be influenced not only by the ability of intestinal bacteria to metabolize daidzein to equol but also by an individual's metabolic status. Studies in rodent models (Mahn et al., 2005; Knock et al., 2006; Si \& Liu, 2008), have shown that dietary isoflavones supplementation increases antioxidant and eNOS gene expression.

Current evidence from several small studies suggests that omega-3 and soy isoflavone supplementation provides an effective means of reducing arterial stiffness (Pase et al., 2011). There is also a growing body of evidence suggesting that soy food consumption is associated with a significant reduction in ischemic stroke risk (Liang et al., 2007; Liang et al., 2009).

\subsection{Reducing cancers}

Epidemiological studies suggest that populations consuming high levels of soybean products (Asian countries) have both lower incidences of cancer and lower mortality rates for the major tumor types commonly found in Western countries.

The soluble fiber in soy products is claimed to help protect the body from many digestive related cancers (Scheppach et al., 2004). In vitro studies, animal experiments and epidemiological observations have shown that consumption of soybean products reduce cancer risk and it is associated with overall low mortality rates due to prostate (Jacobsen et al., 1998; Lee et al., 2003; Hwang et al., 2009), breast (Wu et al., 1998; Yamamoto et al., 2003) and endometrial cancers (Goodman et al., 1997). In a study of 59 countries, soy products were found to be significantly protective with an effect size per kilocalorie at least four times greater than that of any dietary factor (Lee et al., 2003).

Soybean contains a variety of phytochemicals with demonstrated anticancer activity (Park et al., 2005). The most widely studied bioactive substances are the isoflavones and the Bowman-Birk protease inhibitor (BBI). The chemopreventive properties of soybean isoflavones have been attributed to different biological activities, mainly to their long-term 
estrogenic effects and their antioxidant activity (McCue \& Shetty, 2004). BBI works by inhibiting proteases involved in initiation and promotion of carcinogenesis (Kennedy et al., 1998). Its capacity for preventing or suppressing carcinogenic processes has been demonstrated in different cell lines as well as in a wide variety of in vitro and in vivo animal model systems (Losso, 2008). It is currently being evaluated in large-scale human trials as an anti-carcinogenic agent in its less pure form BBI concentrate (Losso, 2008).

Other soy proteins, including lectins and the more recently discovered peptide lunasin, may contribute to the role of soy in the prevention and/or treatment of cancer (HernándezLedesma et al., 2009). The processing of soy protein into peptides in the gastro-intestinal tract greatly increases their healthful effects by exposing active groups within the amino acid chain. Lunasin, one of the most promising of these peptides, has been shown in recent studies to be an effective anti-cancer agent. Found in a variety of readily available foods, lunasin is an accessible component to healthy living (Hernández-Ledesma et al., 2009).

Consumption of soy may also reduce the risk of colon cancer, possibly due to the presence of sphingolipids (Symolon et al., 2004).

Dietary factors present in soybean foods have also been implicated in the etiology of breast cancer and soy isoflavones has been a candidate for dietary intervention. The majority of the studies describe a benefit of soy products; a few studies do not show benefits. In the breast, soy intake during childhood and adolescence might provide lifelong protection against breast cancer and sensitize for the protective effects of adult soy intake (Korde et al., 2009; Lee et al., 2009; Wu et al 2002).

In 2006 the American Cancer Society (ACS) issued some key information on soy-derived foods indicating they are an excellent food source and a good alternative to meat (Doyle et al., 2006). The ACS recommends that breast cancer survivors should consume only moderate amounts of soy foods as part of a healthy plant-based diet. Although two recent human studies in breast cancer survivors did not indicate adverse effects (Guha et al., 2009; Shu et al., 2009) and suggest a reduction in the risk of recurrence in Asian women consuming soy regularly, more studies are needed to determine whether Western soy products or isoflavone supplements are safe for women diagnosed with breast cancer. Furthermore, the ACS advises these same individuals against the deliberate ingestion of large amounts of soy products in the diet and discourages the consumption of concentrated sources of soy like those found in pills, powders, or supplements containing isolated or concentrated isoflavones.

Inconclusive evidence from epidemiological studies, a small number of prospective studies and errors in the estimation of soy and isoflavone intake, in addition to the existence of hidden sources of soy makes it difficult to address this research accurately. There is a need for more prospective studies - with extensive exposure measurement. To interpret the data, isoflavone dose, forms and sources of isoflavone, timing of isoflavone exposure, and the equol producer status, estrogen-receptor status, and hormonal profile of individuals, need to be considered since they potentially modulate the association between soy intake and cancer risk. Other dietary, environmental, and genetic factors may also modify the association. Future studies need to address these questions by including samples large enough to detect the factors that are capable of modifying the associations between soy and cancer risk.

\subsection{Reducing menopausal symptoms}

Isoflavones have emerged as alternatives to classical hormonal therapy in menopause, yet there are still conflicting reports on their vascular health benefits. Recent evidence in 
postmenopausal women supplemented with genistein for six months reveals a significant improvement in glycemic control and endothelial function compared to a placebo group (Villa et al., 2009). These investigators emphasized that an individual's pre-existing metabolic status may affect responses to isoflavone therapy.

Studies evaluating the effectiveness of soy foods in ameliorating vasomotor and vaginal symptoms have been conducted and have utilized a variety of soy foods containing different amounts of isoflavones. Among these studies the results are diverse, 10 studies published in the last 20 years, some have had negative results and one reported worsening of symptoms in the group consuming soy food. Some studies have assessed only vaginal cytology, one study has assessed vasomotor symptoms and reported a reduction in symptoms. Two studies evaluated both outcomes, with opposite findings. In conclusion, considering the conflicting results provided by a small number of studies, the efficacy of soy foods in improving menopausal symptoms remains unclear [for extensive review see Levis \& Griebeler, 2010].

Noteworthy, the beneficial effects of soy are more convincing if soy has been consumed throughout life rather than if the intake starts at menopause (Mardon et al., 2008; Piekarz et al., 2007).

\subsection{Improving bone health}

Studies in Asia found a link between greater intake of isoflavones and stronger bones. Japanese women have a lower rate of hip fractures than American women, but that might be because of genetics or other factors. Clinical observations have suggested a relationship between osteoarthritis and a changed estrogen metabolism in menopausal women. Moreover phytoestrogens have been shown to ameliorate various menopausal symptoms (Claassen et al., 2008). The effect of phytoestrogens, including genistein, has been studied on articular cartilage matrix metabolism and inflammation. Nevertheless, the data for genistein and osteoarthritis are limited and not consistent to support a beneficial effect of genistein on articular cartilage. Genistein does not affect cartilage metabolism (Claassen et al., 2008; Hooshmand et al., 2007) but could have an anti-inflammatory effect by suppressing COX-2 but not nitric oxide production (Hooshmand et al., 2007). In addition, the consumption of an extract of soy phytoestrogen in animal failed to modify cartilage metabolism in ovariectomised monkey (Ham et al., 2004). Additional experiments are needed to clarify the potential benefit of genistein in articular cartilage metabolism.

More recently, basic scientific research studies and a systematic review and meta-analysis of the available high-quality randomized clinical trials indicate that $300 \mathrm{mg}$ of avocado and soybean unsaponifiables per day (with or without glucosamine and chondroitin sulfate) appears to be beneficial for patients with hip or knee osteoarthritis (Dinubile, 2010).

\subsection{Improving diabetic conditions}

Animal and human studies have been conducted to investigate antidiabetic effects of soybeans and their actions (Trujillo et al., 2005; Chandalia et al., 2000; Pipe et al., 2009; Azadbakht et al., 2008). Previous observations have shown that soya-containing diets were associated with an improvement in insulin resistance and glycemic control (Kwon et al., 2010). It has also been suggested that the protein and fiber found in soy help to regulate blood glucose levels and kidney filtration, thereby, helping to control diabetic complications along with kidney disease. Hence, soybeans may help prevent type 2 diabetes and delay its progression. 
Soybean diet may be a good option in type 2 diabetes individuals due to its effect on hypertension, hypercholesterolemia, atherosclerosis and obesity, which are frequently associated with diabetic disease (Holt et al., 1996).

In addition, substituting animal protein for soybean or other vegetable protein may also decrease renal hyperfiltration, proteinuria, and renal acid load and therefore reduces the risk of renal disease in type 2 diabetes (Jenkins et al., 2003).

It is generally accepted that a high fiber diet, particularly soluble fiber, is useful to control plasma glucose concentration in diabetics. Soybean fiber may be useful because of its insulin-moderated effect. In short- and long-term experiments it has been reported an improvement in blood glucose attributed to fiber intake from soybeans (Messina, 1999; Chandalia et al., 2000). The mechanisms to improve glycemic control during dietary fiber intake seem to be due to the effects of slowing carbohydrate absorption, so that dietary fiber reduces or delays the absorption of carbohydrates. Soybean dietary fiber also increases faecal excretion of bile acid and therefore may cause a low absorption of fat (Chandalia et al., 2000; Jenkins et al., 2003) and reduces the caloric density in some foods (Liu, 1999).

Additionally, an increased consumption of n-3 PUFA coupled with a reduced intake of saturated fat has been suggested to reduce the risk of progression from impaired glucose tolerance to type 2 diabetes in overweight subjects (Nettleton \& Katz, 2005). We have previously shown that after 8 weeks of treatment with soybean oil young Goto-Kakizaki (GK) rats had a significant decrease in glycated haemoglobin accompanied by a significant decrement in fasting blood glucose levels (Sena et al., 2008b). The improved diabetic profile is probably due to the soybean oil antioxidant composition, namely $\alpha$-tocopherol and coenzyme Q. Moreover, it has recently been described that dietary phytoestrogens activate AMP-activated protein kinase with improvement in lipid and glucose metabolism (Cederroth et al., 2008), thus other constituents may be involved.

Isoflavones are structurally and functionally similar to estradiol (Knight \& Eden, 1996). Thus, soy isoflavones may improve glucose homeostasis through their estrogenic action. The estrogen receptor $\alpha$ is emerging as a key molecule involved in glucose and lipid metabolism. Isoflavones may have antidiabetic actions through estrogen receptors.

Soybean isoflavones and protein consumption alleviate some of the symptoms associated with type 2 diabetes (Davis et al., 2005; Mezei et al., 2003). However, human clinical trials are contradictory (Sites et al., 2007; González et al., 2007). Some studies report that consumption of isolated isoflavones did not affect insulin sensitivity as assessed by an oral 2-hour glucose tolerance test in a crossover study of postmenopausal women, even though serum ghrelin levels were decreased by the isoflavonoid treatment, indicating some changes in appetite (Nikander et al., 2004). In addition, insulin secretion, visceral fat, total body fat, and lean body mass did not change among postmenopausal women who consumed soy protein for 3 months compared with those that consumed casein protein (Sites et al., 2007). A 6-month randomized controlled trial did not support the hypothesis that soy protein with or without isoflavone supplementation had favorable effects on glycemic control and insulin sensitivity among postmenopausal Chinese women (Liu et al., 2010). A recent meta-analysis of 24 trials and more than 1,500 subjects reported no significant overall effect of soy intake on fasting glucose and insulin concentrations. There were not enough trials to generate sufficient evidence for other glycemic variables, such as HbA1c and 2-h postchallenge glucose and insulin concentrations (Liu et al., 2011). However, some studies have shown positive effects. For instance, postmenopausal women taking dietary supplementation with 
phytoestrogens had significantly improved glycemic control, insulin resistance and serum lipoproteins (Jayagopal et al., 2002; González et al., 2007). In a recent meta-analysis of randomized clinical trials, there was a favorable change in fasting glucose concentrations observed in studies that used whole soy foods or a soy diet in the subgroup analysis (Liu et al., 2011).

Recent experiments have shown that isoflavones in soybeans enhance insulin secretion and insulin sensitivity in experimental animal models of diabetes (Lu et al., 2008; Cederroth et al., 2008; Noriega-López et al., 2007), and that soy protein attenuates insulin resistance in male Sprague-Dawley rats (Ronis et al., 2009). Phytoestrogens seem to modulate energy expenditure, adiposity and glucose tolerance in rodents (for review see Cederroth \& Nef, 2009). However, the effect of isoflavones and soy protein remains unclear, although several studies have revealed mechanisms by which soy isoflavones may impact glucose metabolism (Ronis et al., 2009).

Soy foods are beneficial for decreasing the risk of onset and progression of insulin resistance and type 2 diabetes and the effectiveness is enhanced by fermentation. Phytoestrogens and proteins in soybeans seem to have beneficial actions, and additional micronutrients such as saponins, phytosterols, trypsin inhibitors, as well as the amino acid and protein composition may have additive or synergistic effects. Fermentation of soybeans leads to structural changes in proteins and phytoestrogen, which may contribute to more beneficial effects on glucose metabolism. Investigating soybeans and fermented soy products have not used standardized formulations, doses, routes of exposure, durations of exposure, and subsequent analyses to evaluate antidiabetic effects and mechanisms of action.

Studies performed in diabetic patients with soybean diets show several potential advantages, but at the moment more work is required to define the exact role of soybean in the control of diabetes mellitus.

\section{Opposing viewpoints on the health benefits of soybeans}

Currently, there are opposing viewpoints on the health benefits of soy products. Some studies suggest that soy is linked to health problems including: malnutrition, digestive distress, thyroid dysfunction, cognitive decline, reproductive disorders, infertility, birth defect, immune system breakdown, and cancer (Leopald, 1976; Setchell et al., 1987; Doerge, 2002; Helferich et al., 2008; Xiao, 2008; Patisaul \& Jefferson, 2010; Cederroth et al., 2010, BarEl \& Reifen, 2010).

Soybeans contain haemagglutinin, a clot-promoting substance. Haemagglutinin and trypsin inhibitors can act as growth inhibitors. Weanling rats fed soy containing these antinutrients fail to grow normally. However, these growth-depressant compounds are deactivated during the process of fermentation (Borchers, 1962).

A very large percentage of soy is genetically modified (more than $99 \%$ ) and it also has one of the highest percentages of contamination by pesticides. Recent studies on safety assessment of genetically modified soybeans showed rather contradictory results. Two research groups have been especially active in relation to those investigations. One of them, headed by Dr. Delaney from Pioneer Hi-Bred International, Inc. (Johnston, IA, USA), has reported data showing that various genetically modified soybeans were safe. In contrast, the group headed by Dr. Malatesta from the University of Verona (Verona, Italy) has shown notable concerns (Delaney et al., 2008; Malatesta et al., 2008a; Malatesta et al., 2008b). Certain pesticides are known to increase the incidence of several types of cancers 
(Weichenthal et al., 2010). Thus, contamination of soybeans with pesticides may explain the increase risk of certain types of cancer.

The soybean has one of the highest phytate levels of any grain or legume that has been studied (El Tinay, 1989), and the phytates in soy are highly resistant to normal phytatereducing techniques such as long, slow cooking (Ologhobo et al., 1984). Only a long period of fermentation will significantly reduce the phytate content of soybeans. Phytates can block the uptake of essential minerals - calcium, magnesium, copper, iron and especially zinc - in the intestinal tract. Diets high in phytates contribute to widespread mineral deficiencies in third world countries (Moser et al., 1988; Harland et al., 1988).

When soy products like tofu are consumed with meat, the mineral-blocking effects of the phytates are reduced (Sandström et al., 1989). The Japanese traditionally eat a small amount of tofu or miso as part of a mineral-rich fish broth, followed by a serving of meat or fish. However, vegetarians who consume tofu and bean curd as a substitute for meat and dairy products risk severe mineral deficiencies.

Zinc is needed for the optimal development and functioning of the brain and nervous system (Takeda \& Tamano, 2009). It plays a role in protein synthesis and collagen formation; it is involved in the blood-sugar control mechanism and thus protects against diabetes (Jansen et al., 2009); it is also needed for a healthy reproductive system (Eickhoff et al., 2004). Zinc is a key component in numerous vital enzymes and plays a role in the immune system. Phytates found in soy products interfere with zinc absorption more completely than with other minerals (Greger, 1999).

Soy protein isolate (SPI) is the key ingredient in most soy foods that imitate meat and dairy products, including baby formulas and some brands of soy milk. Much of the trypsin inhibitor content can be removed through high-temperature processing, but not all. Trypsin inhibitor content of soy protein isolate can vary as much as fivefold (Rackis et al., 1986). But high-temperature processing has the unfortunate side-effect of so denaturing the other proteins in soy that they are rendered largely ineffective (Wallace et al., 1971a; Wallace et al., 1971b). Thus, animal models feed with soybean diets need aminoacid supplements for normal growth.

In feeding experiments, the use of SPI increased requirements for vitamins E, K, D and B12 and created deficiency symptoms of calcium, magnesium, manganese, molybdenum, copper, iron and zinc (Rackis, 1974). Phytic acid remaining in these soy products greatly inhibits zinc and iron absorption; test animals fed SPI develop enlarged organs, particularly the pancreas and thyroid gland, and increased deposition of fatty acids in the liver (Rackis, 1974).

Soy protein isolate and textured vegetable protein are used extensively in school lunch programs, commercial baked goods, diet beverages and fast food products. "Nutritional Quality of Soy Bean Protein Isolates: Studies in Children of Preschool Age", studied a group of Central American children suffering from malnutrition. Researchers did not use soy products to help the children recover from malnutrition. Instead, a supplement with soysugar mixture and nutrients (largely absent in soy products - notably, vitamins A, D and B12, iron, iodine and zinc) was used.

\subsection{Isoflavones have harmful side effects}

Phytoestrogens tend to have weaker effects than most estrogens, are not stored in the body, and can be easily broken down and eliminated. They are considered to be endocrine disrupting compounds, and have some beneficial effects on health, including reducing the 
risk of breast cancer and improving metabolic parameters. However, the supporting evidence that consumption of phytoestrogens is beneficial is indirect and inconsistent. Lifetime exposure to estrogenic substances, especially during critical periods of development, has been associated with formation of malignancies and several anomalies of the reproductive systems (Cederroth et al., 2010). Isoflavones can prevent ovulation and actually stimulate cancer cell growth (Bar-El \& Reifen, 2010).

Soy products in western countries are quite different from those consumed in the traditional Asian diet. Most Asian soy products use whole soybeans with or without fermentation. Soy products or second generation soy foods in the US are mostly based on soy protein at different levels of purification or extraction such as texturized vegetable protein $(45 \%$ protein), soy protein concentrate ( $70 \%$ protein), or isolates $(90 \%$ protein), each with a different profile of nutrient and non-nutrient compounds, including isoflavones and saponins (Setchell \& Cole, 2003; Fang et al., 2004). It is likely that processing of soy foods modulates the profile of isoflavones and modifies their bioaccesibility and bioavailability, but how these differences affect cancer risk and risk of recurrence need to be investigated.

\subsection{Soy milk and infants}

It has been previously suggested that the highly concentrated phytoestrogens in soy formula might weaken the immune systems of infants. The authors have suggested potential immune, reproductive and endocrine effects in infants or adults as a result of high isoflavone consumption in the soy formulas (Yellayi et al., 2002). The formulas have more of these compounds than soy foods do. There's no evidence that soy formula is unsafe, or that infants drinking it have been harmed (Yellayi et al., 2002). However, breast milk is still the first choice, followed by milk-based formulas. Moreover, only infants allergic to milk should drink soy formula (Setchell et al., 1997).

\subsection{Thyroid disease}

Soy also contains goitrogens - substances that depress thyroid function. Diffuse goiter and hypothyroidism appeared in some of the subjects consuming soybeans and many complained of constipation, fatigue and lethargy, even though their intake of iodine was adequate (Ishizuki et al., 1991). In 1997, researchers from the FDA's National Center for Toxicological Research reported that the goitrogenic components of soy were the isoflavones (Divi et al., 1997). It has been previously suggested that soy protein supplements can interfere with the absorption of thyroid medications (Drane et al., 1980). One study showed that soy foods may actually interfere with normal thyroid function, perhaps leading to goiter (Kimura et al., 1976).

There's no risk of goiter in healthy people consuming soy that are not deficient in iodine. Strict vegetarians, who eat no iodine-rich fish or dairy products, might be at risk-and eating higher amounts of soy might increase the risk. A healthy balanced diet with the appropriate amounts of soy and iodine intake is essential (Fitzpatrick, 2000).

\subsection{Kidney stones}

People with higher risk of development of calcium-oxalate kidney stones should limit their intake of soy. Many soy foods are rich in oxalates and thus may promote the formation of such stones in those at risk (Al-Wahsh et al., 2005). On the other hand, soybean is associated with health benefits for patients with gallstones. The mechanism of beneficial effect of 
soybean on gallstones is not well known but it may be related to the blood cholesterol lowering effects of soybean protein containing isoflavones (Holt et al., 1996).

\section{Conclusion}

Soy foods have been consumed for centuries in Asian countries. Many potential benefits have been linked to intake of soy products according to epidemiological investigations. For instance, consumption of soy foods may contribute to lower incidences of coronary heart diseases, atherosclerosis, type 2 diabetes, and decreased risk of certain types of cancer such as breast and prostate cancers as well as better bone health and relief of menopausal symptoms.

The American Dietetic Association's position on vegetarian diets indicates that certain eating patterns may reduce risk of chronic disease, and soy products and phytochemicals are included in the list of influential dietary factors (Nitzke \& Freeland-Graves, 2007; Craig \& Mangels, 2009). Moreover they also acknowledged that even foods associated with a healthful diet, such as soybeans, should not be viewed oversimplistically as being ideal, or good or bad, but instead their value should be ascertained within the context of the total diet.

Perhaps an effort to investigate whole soy, knowing that more than one component of this food is likely implicated if appreciable health benefits can be attributed to its consumption outside of Asian populations.

\section{References}

Adams, M.R., Golden, D.L., \& Register, T.C., Anthony, M.S., Hodgin, J.B., Maeda, N., Williams, J.K. (2002). The atheroprotective effect of dietary soy isoflavones in apolipoprotein $\mathrm{E}-/-$ mice requires the presence of estrogen receptor-alpha. Arteriosclerosis, Thrombosis and Vascular Biology, Vol.22, No.11, (November 2002), pp. 1859-1864, ISSN 1079-5642

Adams, M.R., Golden, D.L., Franke, A.A., Potter, S.M., Smith, H.S., \& Anthony, M.S. (2004). Dietary soy beta-conglycinin (7S globulin) inhibits atherosclerosis in mice. Journal of Nutrition, Vol.134, No.3, (March 2004), pp. 511-516, ISSN 1541-3166

Adlercreutz, H. (2002). Phyto-oestrogens and cancer. Lancet Oncolology, Vol.3, No.6, (June 2002), pp. 364-373, ISSN 1470-2045

Al-Wahsh, I.A., Horner, H.T., Palmer, R.G., Reddy, M.B., \& Massey, L.K. (2005). Oxalate and phytate of soy foods. Journal of Agricultural and Food Chemistry, Vol. 53, No.14, (July 2005), pp. 5670-5674, ISSN 0021-8561

Anderson, J.W. (2008). Beneficial effects of soy protein consumption for renal function. Asia Pacific Journal of Clinical Nutrition, Vol.17, Suppl.1, (January 2008), pp.324-328, ISSN 0964-7058

Anderson, J.W., Johnstone, B.M., \& Cook, N. (1995). Meta-analysis of the effects of soy protein intake on serum lipids. The New England Journal of Medicine, Vol.333, No.5, (August 1995), pp. 276-282, ISSN 0028-4793

Anderson, J.W., Smith, B.M., \& Washnock, C.S. (1999). Cardiovascular and renal benefits of dry bean and soybean intake. The American Journal of Clinical Nutrition, Vol.70, Suppl.3, (September 1999), pp. 464-474, ISSN 0002-9165

Anthony, M.S., Clarkson, T.B., Bullock, B.C., \& Wagner, J.D. (1997). Soy protein versus soy phytoestrogens in the prevention of diet-induced coronary artery atherosclerosis of male cynomolgus monkeys. Arteriosclerosis, Thrombosis and Vascular Biology, Vol.17, No.11, (November 1997), pp. 2524-2531, ISSN 1079-5642 
Azadbakht, L., Atabak, S., \& Esmaillzadeh, A. (2008). Soy protein intake, cardiorenal indices, and C-reactive protein in type 2 diabetes with nephropathy: a longitudinal randomized clinical trial. Diabetes Care, Vol.31, No.4, (April 2008), pp. 648-654, ISSN 0149-5992

Balk, E., Chung, M., Chew, P., Ip, S., Raman, G., Kupelnick, B., Tatsioni, A., Sun, Y., Devine, \& D., Lau, J. (2005). Effects of soy on health outcomes. Evidence Report Technology Assessment (Summaries), Vol.126, (August 2005), pp. 1-8, ISSN 1530-440X

Bar-El, D.S., \& Reifen, R. (2010). Soy as an endocrine disruptor: cause for caution? Journal of Pediatric Endocrinology and Metabolism, Vol.23, No.9, (September 2010), pp. 855-861, ISSN 0334-018X

Borchers, R. (1962). Supplementary methionine requirement of wenling rats fed soybean oil meal rations. Journal of Nutrition, Vol.77, No.3, (July 1962), pp. 309-311, ISSN 15413166

Bosaeus, I. (2004). Fibre effects on intestinal functions (diarrhoea, constipation and irritable bowel syndrome). Clinical Nutrition Supplements, Vol.1, No.2, (2004), pp. 33-38, ISSN 1744-1161

Buttery, B.R., \& Buzzell, R.I, (1975). Soybean flavonol glycosides: identification and biochemical genetics. Canadian Journal of Botany, Vol.53, No.2, (January 1975), pp. 219-224, ISSN 1916-2804

Cassidy, A., Brown, J.E., Hawdon, A., Faughnan, M.S., King, L.J., Millward, J., ZimmerNechemias, L., Wolfe, B., \& Setchell, K.D. (2006). Factors affecting the bioavailability of soy isoflavones in humans after ingestion of physiologically relevant levels from different soy foods. Journal of Nutrition, Vol.136, No.1, (2006), pp. 45-51, ISSN 1541-3166

Cederroth, C.R., \& Nef, S. (2009). Soy, phytoestrogens and metabolism: A review. Molecular Cellular Endocrinology, Vol.304, No.1, (May 2009), pp. 30-42, ISSN 0303-7207

Cederroth, C.R., Auger, J., Zimmermann, C., Eustache, F., \& Nef, S. (2010). Soy, phytooestrogens and male reproductive function: a review. International Journal of Androlology, Vol.33, No.2, (April 2010), pp. 304-316, ISSN 0105-6263

Cederroth, C.R., Vinciguerra, M., Gjinovci, A., Kühne, F., Klein, M., Cederroth, M., Caille, D., Suter, M., Neumann, D., James, R.W., Doerge, D.R., Wallimann, T., Meda, P., Foti, M., Rohner-Jeanrenaud, F., Vassalli, J.D., \& Nef, S. (2008). Dietary phytoestrogens activate AMP-activated protein kinase with improvement in lipid and glucose metabolism. Diabetes, Vol.57, No.5, (May 2008), pp. 1176-1185, ISSN 0012-1797

Chandalia, M., Garg, A., Lutjohann, D., Von Bergmann, K., Grundy, S.M., \& Brinkley, L.J. (2000). Beneficial effects of high dietary fiber intake in patients with type 2 Diabetes Mellitus. The New England Journal of Medicine, Vol.342, No.19, ( May 2000), pp. $1392-$ 1398, ISSN 0028-4793

Claassen, H., Briese, V., Manapov, F., Nebe, B., Schunke, M., \& Kurz, B. (2008). The phytoestrogens daidzein and genistein enhance the insulin-stimulated sulfate uptake in articular chondrocytes. Cell and Tissue Research, Vol.333, No.1, (July 2008), pp. 71-79, ISSN 0302-766X

Clair, R.S, \& Anthony, M. (2005). Soy, isoflavones and atherosclerosis. Handbook of Experimental Pharmacolology, Vol.170, (2005), pp. 301-323, ISSN 0171-2004

Clarkson, T.B. (2002). Soy, soy phytoestrogens and cardiovascular disease. Journal of Nutrition, Vol.132, No.3, (March 2002), pp. 566S-569S, ISSN 1541-3166 
Craig, W.J., \& Mangels, A.R. (2009). Position of the American Dietetic Association. Vegetarian diets. Journal of the American Dietetic Association, Vol.109, No.7, (July 2009), 1266-1282, ISSN 0002-8223

Damodaran S. Amino acids, peptides, and proteins. In: Fennema OW, editor. Food chemistry. 4rd ed. New York: Marcel Dekka, Inc. (September 2007), p.321-429, ISBN: 9780849392726

Davis, J., Iqbal, M.J., Steinle, J., Oitker, J., Higginbotham, D.A., Peterson, R.G., \& Banz, W.J. (2005). Soy protein influences the development of the metabolic syndrome in male obese ZDFxSHHF rats. Hormone and Metabolic Research, Vol.37, No.5, (May 2005), pp. 316-325, ISSN 0018-5043

Delaney, B., Appenzeller, L.M., Munley, S.M., Hoban, D., Sykes, G.P., Malley, L.A., \& Sanders, C. (2008). Subchronic feeding study of high oleic acid soybeans (event DP3Ø5423-1) in Sprague-Dawley rats. Food and Chemical Toxicology, Vol.46, No.12, (December 2008), pp. 3808-3817, ISSN 0278-6915

Dinubile NA. (2010). A potential role for avocado- and soybean-based nutritional supplements in the management of osteoarthritis: a review. The Physician and Sportsmedicine, Vol.38, No.2, (June 2010), pp. 71-81, ISSN 0091-3847

Divi, R.L., Chang, H.C., \& Doerge, D.R. (1997). Anti-thyroid isoflavones from the soybean. Biochemical Pharmacology, Vol.54, No.10, (November 1997), pp. 1087-1096, ISSN 0006-2952

Doerge, D.R. (2002). Goitrogenic and estrogenic activity of soy isoflavones. Environmental Health Perspectives, Vol.110, Suppl.3, (June 2002), pp. 349-353, ISSN 0091-6765

Doyle, C., Kushi, L.H., Byers, T., Courneya, K.S., Demark-Wahnefried, W., Grant, B., McTiernan, A., Rock, C.L., Thompson, C., Gansler, T., \& Andrews, K.S. (2006). Nutrition and physical activity during and after cancer treatment: an American Cancer Society guide for informed choices. CA: a Cancer Journal for Clinicians, Vol.56, No.6, (November-December 2006), pp. 323-353, ISSN 0007-9235

Drane, H.M., Patterson, D.S., Roberts, B.A., \& Saba, N. (1980). Oestrogenic activity of soyabean products. Food, Cosmetics and Technology, Vol.18, No.4, (August 1980), pp.425427, ISSN 0015-6264

Eickhoff, R., Baldauf, C., Koyro, H.W., Wennemuth, G., Suga, Y., \& Seitz, J. (2004). Influence of macrophage migration factor (MIF) on the zinc content and redox state of protein-bound sulfhydryl groups in rat sperm: indications for a new role of MIF in sperm maturation, Molecular Human Reproduction, Vol.10, No.8, (August 2004), pp. 605-611, ISSN 1360-9947

El Tinay, A.H., Mahgoub, S.O., Mohamed, B.E., \& Hamad, M.A. (1989). Proximate Composition and Mineral and Phytate Contents of Legumes Grown in Sudan. Journal of Food Composition and Analysis, Vol.2, No.1, (March 1989), pp. 69-78, ISSN 0889-1575

Fang, N., Yu, S., \& Badger, T.M. (2004). Comprehensive phytochemical profile of soy protein isolate. Journal of Agricultural and Food Chemistry, Vol.52, No.12, (June 2004), pp. 4012-4020, ISSN 0021-8561

Fitzpatrick, M. (2000). Soy formulas and the effects of isoflavones on the thyroid. The New Zealand Medical Journal, Vol.113, No.1103, (February 2000), pp. 24-26, ISSN: 00288446

Food and Drug Administration (FDA). FDA approves new health claim for soybean protein and coronary heart disease. FDA Talk Paper 1999, [cited 2011 Mar 25], In: www.fda.gov 
Friedman, M., \& Brandon, D.L. (2001). Nutritional and health benefits of soy proteins. Journal of Agricultural and Food Chemistry, Vol.49, No.3, (March 2001), pp. 1069-1086, ISSN 0021-8561

Garcia, M.C., Torre, M., Marina, M.L., \& Laborda, F. (1997). Composition and characterization of soybean and related products. Critical Reviews in Food Science and Nutrition, Vol.37, No.4, (June 1997), pp. 361-391, ISSN 1040-8398

González, S., Jayagopal, V., Kilpatrick, E.S., Chapman, T., \& Atkin, S.L. (2007). Effects of isoflavone dietary supplementation on cardiovascular risk factors in type 2 diabetes. Diabetes Care, Vol.30, No.7, (July 2007), pp. 1871-1873, ISSN 0149-5992

Goodman, M.T., Wilkens, L.R., Hankin, J.H., Wu, A.H., \& Kolonel, L.N. (1997). Association of soy and fiber consumption with the risk of endometrial cancer. American Journal of Epidemiology, Vol.146, No.4, (August 1997), pp.294-306, ISSN 0002-9262

Greger, J.L. (1999) Nondigestible carbohydrates and mineral bioavailability. Journal of Nutrition, Vol.129, Suppl.7, (July 1999), pp. 1434S-1435S, ISSN 1541-3166

Guha, N., Kwan, M.L., Quesenberry, C.P. Jr., Weltzien, E.K., Castillo, A.L., \& Caan, B.J. (2009). Soy isoflavones and risk of cancer recurrence in a cohort of breast cancer survivors: the Life After Cancer Epidemiology study. Breast Cancer Research and Treatment, Vol.118, No.2, (November 2009), pp. 395-405, ISSN 0167-6806

Gullett, N.P., Ruhul,Amin, A.R., Bayraktar, S., Pezzuto, J.M., Shin, D.M., Khuri, F.R., Aggarwal, B.B., Surh, Y.J., \& Kucuk, O. (2010). Cancer prevention with natural compounds. Seminars in Oncology, Vol.37, No.3, (June 2010), pp. 258-281, ISSN 00937754

Ham, K.D., Oegema, T.R., Loeser, R.F., \& Carlson, C.S. (2004). Effects of longterm estrogen replacement therapy on articular cartilage IGFBP-2, IGFBP-3, collagen and proteoglycan levels in ovariectomized cynomolgus monkeys. Osteoarthritis Cartilage, Vol.12, No.2, (February 2004), pp. 160-168, ISSN 1063-4584

Harland, B.F., Smith, S.A., Howard, M.P., Ellis, R., \& Smith, J.C. Jr. (1988). Nutritional status and phytate: zinc and phytate $\mathrm{X}$ calcium: zinc dietary molar ratios of lactoovovegetarian Trappist monks: 10 years later. Journal of the American Dietetic Association, Vol.88, No.12, (December 1988), pp. 1562-1566, ISSN 0002-8223

He, J., Gu, D., Wu, X., Chen, J., Duan, X., Chen, J., \& Whelton, P.K. (2005). Effect of soybean protein on blood pressure: a randomized, controlled trial. Annals of Internal Medicine, Vol.143, No.1, (July 2005), pp. 1-9, ISSN 0003--4819

Helferich, W.G., Andrade, J.E., \& Hoagland, M.S. (2008). Phytoestrogens and breast cancer: a complex story. Inflammopharmacology, Vol.16, No.5, (October 2008), pp. 219-226, ISSN 0925-4692

Henkel, J. (2000). Soybean: Health claims for soybean protein, questions about other components. FDA Consumer 2000, [cited 2011 Mar 25]., In www.cfsan.fda.gov

Hernández-Ledesma, B., Hsieh, C.-C., \& de Lumen, B.O. (2009). Lunasin, a novel seed peptide for cancer prevention. Peptides, Vol.30, No.2, (February 2009), pp. 426-430, ISSN 0196-9781

Holt, S., Muntyan, I., \& Likyer, L. (1996). Soybean-based diets for Diabetes Mellitus. Alternative \& Complementary Therapies, Vol.2, No.2, (March/April 1996), pp. 79-92, ISSN 1557-9085

Hooshmand, S., Soung do, Y., Lucas, E.A., Madihally, S.V., Levenson, C.W., \& Arjmandi, B.H. (2007). Genistein reduces the production of proinflammatory molecules in human chondrocytes. Journal of Nutrition Biochemistry, Vol.18, No.9, (September 2007), pp. 609-614, ISSN 0955-2863 
Hwang, Y.W., Kim, S.Y., Jee, S.H., Kim, Y.N., \& Nam, C.M. (2009). Soy food consumption and risk of prostate cancer: a meta-analysis of observational studies. Nutrition Cancer, Vol.61, No.5, ( 2009), pp.598-606, ISSN 0163-5581

Ishizuki, Y., Hirooka, Y., Murata, Y., \& Togashi, K. (1991). The effects on the thyroid gland of soybeans administered experimentally in healthy subjects. Nippon Naibunpi Gakkai Zasshi Vol.767, No.1 (May 1991), pp. 622-629, ISSN 0916-4804

Jacobsen, B.K., Knutsen, S.F., \& Fraser, G.E. (1998). Does high soy milk intake reduce prostate cancer incidence? The adventist health study (United States). Cancer Causes Control, Vol.9, No.6, (December 1998), pp. 553-557, ISSN 0957-5243

Jansen, J., Karges, W., \& Rink, L. (2009). Zinc and diabetes-clinical links and molecular mechanisms. Journal of Nutrition Biochemistry, Vol.20, No.6, (June 2009), pp. 399-417, ISSN 0955-2863

Jayagopal, V., Albertazzi, P., Kilpatrick, E.S., Howarth, E.M., Jennings, P.E., Hepburn, D.A., Atkin, S.L. (2002). Beneficial effects of soy phytoestrogen intake in postmenopausal women with type 2 diabetes. Diabetes Care, Vol.25, No.10, (October 2002), pp. 17091714, ISSN 0149-5992

Jenkins, D.J., Kendall, C.W., Augustin, L.S., Franceschi, S., Hamidi, M., Marchie, A., Jenkins, A.L., \& Axelsen, M. (2002). Glycemic index: overview of implications in health and disease. American Journal of Clinical Nutrition, Vol.76, No.1, (July 2002), pp. 266S273S, ISSN 0002-9165

Jenkins, D.J., Kendall, C.W., Marchie, A., Jenkins, A.L., Augustin, L.S., Ludwig, D.S., Barnard, N.D., \& Anderson, J.W. (2003). Type 2 diabetes and vegetarian diet. American Journal of Clinical Nutrition, Vol.78, Suppl.3, (September 2003), pp. 610S616S, ISSN 0002-9165

Kennedy, A.R. (1998). The Bowman-Birk inhibitor from soybeans as an anticarcinogenic agent. American Journal of Clinical Nutrition, Vol.68, Suppl.6, (December 1998), pp. 1406S-1412S, ISSN 0002-9165

Kimura, S., Suwa, J., Ito, M., \& Sato, H. (1976). Development of malignant goiter by defatted soybean with iodine-free diet in rats. Gann, Vol.67, No.5, (October 1976), pp. 763765, ISSN 0016-450X

Knight, D.C., \& Eden, J.A. (1996). A review of the clinical effects of phytoestrogens. Obstetrics and Gynecolology, Vol.87, No.5, Pt2, (May 1996), pp.897-904, ISSN 00297844

Knock, G.A., Mahn, K., Mann, G.E., Ward, J.P., \& Aaronson, P.I. (2006). Dietary soy modulates endothelium-dependent relaxation in aged male rats: increased agonistinduced endothelium-derived hyperpolarising factor and basal nitric oxide activity. Free Radical Biology \& Medicine, Vol.41, No.5, (September 2006), pp.731-739, ISSN 0891-5849

Korde, L.A., Wu, A.H., \& Fear, T. (2009). Childhood soy intake and breast cancer risk in Asian-American women. Cancer Epidemiology, Biomarkers \& Prevention, Vol.18, No.4, (April 2009), pp.1050-1059, ISSN 1055-9965

Kwon, D.Y., Daily, J.W. 3rd., Kim, H.J., \& Park, S. (2010). Antidiabetic effects of fermented soybean products on type 2 diabetes. Nutrition Research, Vol.30, No.1, (January 2010), pp. 1-13, ISSN 0271-5317

Kwon, D.Y., Kim, S., Kim, H.Y.L., \& Kim, K.S. (2003). Changes in physicochemical properties of glycinin due to maleylation. Food Science \& Biotechnology, Vol.12, No.2, (April 2003), pp.122-127, ISSN 1226-7708

Kwon, D.Y., Oh, S.W., Lee, J.S., Yang, H.J., Lee, S.H., Lee, J.H., Lee, Y.B., Sohn, H.S., \& Lee, J.S. (2002). Amino acid substitution of hypocholesterolemic peptide originated from 
glycinin hydrolyzate. Food Science \& Biotechnology, Vol.11, No.1, (February 2002), pp.55-61, ISSN 1226-7708

Larkin, T., Price, W.E., \& Astheimer, L. (2008). The key importance of soy isoflavone bioavailability to understanding health benefits. Critical Reviews of Food Science Nutrition, Vol.48, No.6, (June 2008), pp.538-552, ISSN 1040-8398

Lee, M.M., Gomez, S.L., Chang, J.S., Wey, M.,Wang, R.T., \& Hsing, A.W. (2003). Soy and isoflavone consumption in relation to prostate cancer risk in china. Cancer Epidemiology Biomarkers \& Prevention, Vol.12, No.7, (July 2003), pp. 665-668, ISSN 1055-9965

Lee, S.A., Shu, X.O., Li, H., Yang, G., Cai, H., Wen, W., Ji, B.T., Gao, J., Gao, Y.T., \& Zheng, W. (2009). Adolescent and adult soy food intake and breast cancer risk: results from the Shanghai Women's Health Study. American Journal of Clinical Nutrition, Vol.89, No.6, (June 2009), pp. 1920-1926, ISSN 0002-9165

Leopald, A.S. (1976). Phytoestrogens: Adverse effects on reproduction in California Quail. Science, Vol.191, No.4222, (January 1976), pp.98-100, ISSN 0036-8075

Levis, S., \& Griebeler, M.L. (2010). The role of soy foods in the treatment of menopausal symptoms. Journal of Nutrition, Vol.140, No.12, (December 2010), pp. 2318S-2321S, ISSN 1541-3166

Li, M., Liu, R.M., Timblin, C.R., Meyer, S.G., Mossman, B.T., \& Fukagawa, N.K. (2006). Age affects ERK1/2 and NRF2 signaling in the regulation of GCLC expression. Journal of Cell Physiology, Vol.206, No.2, (February 2006), pp. 518-525, ISSN 0021-9541

Liang, W., Lee, A.H., Binns, C.W., Hu, D., Huang, R., \& Tian, H. (2007). Are soy foods protective against ischemic stroke? Future Neurology, Vol.2, No. 5, (September 2007), pp. 505-511, ISSN 1479-6708

Liang, W., Lee, A.H., Binns, C.W., Huang, R., Hu, D., \& Shao, H. (2009). Soy consumption reduces risk of ischemic stroke: a case-control study in southern China. Neuroepidemiology, Vol.33, No.2, (2009), pp. 111-116, ISSN 0251-5350

Liu, K.S. (1999). Chemistry and nutritional value of soybean components. In Soybeans: Chemistry, Technology and Utilization. Aspen Publishers Inc. Gaithersburg, Maryland, USA, 1999, pp. 25-113, ISBN 0834212994

Liu, Z.M., Chen, Y.M., Ho, S.C. (2011). Effects of soy intake on glycemic control: a metaanalysis of randomized controlled trials. Americam Journal of Clinical Nutrition, [Epub ahead of print], (2 March 2011), ISSN 0002-9165

Liu, Z.M., Chen, Y.M., Ho, S.C., Ho, Y.P., Woo, J. (2010). Effects of soy protein and isoflavones on glycemic control and insulin sensitivity: a 6-mo double-blind, randomized, placebo-controlled trial in postmenopausal Chinese women with prediabetes or untreated early diabetes. Americam Journal of Clinical Nutrition, Vol.91, No.5, (May 2010), pp.1394-1401, ISSN 0002-9165

Losso, J.N. (2008). The biochemical and functional food properties of the Bowman-Birk Inhibitor. Critical Reviews of Food Science and Nutrition, Vol.48, No.1, (January 2008), pp.94-118, ISSN 1040-8398

Lu, M.P., Wang, R., Song, X., Chibbar, R., Wang, X., Wu, L., \& Meng, Q.H. (2008). Dietary soy isoflavones increase insulin secretion and prevent the development of diabetic cataracts in streptozotocin-induced diabetic rats. Nutrition Research, Vol.28, No.7, (July 2008), pp.464-471, ISSN 0271-5317

Mahn, K., Borras, C., Knock, G.A., Taylor, P., Khan, I.Y., Sugden, D., Poston, L., Ward, J.P., Sharpe, R.M., Vina, J., Aaronson, P.I., \& Mann, G.E. (2005). Dietary soy isoflavone induced increases in antioxidant and eNOS gene expression lead to improved 
endothelial function and reduced blood pressure in vivo. FASEB Journal, Vol.19, No.12, (October 2005), pp. 1755-1757, ISSN 0892-6638

Malatesta, M., Boraldi, F., Annovi, G., Baldelli, B., Battistelli, S., Biggiogera, M., \& Quaglino, D. (2008a). A long-term study on female mice fed on a genetically modified soybean: effects on liver ageing. Histochemistry and Cell Biology, Vol.130, No.5, (November 2008), pp. 967-977, ISSN 0948-6143

Malatesta, M., Perdoni, F., Santin, G., Battistelli, S., Muller, S., \& Biggiogera, M. (2008b). Hepatoma tissue culture (HTC) cells as a model for investigating the effects of low concentrations of herbicide on cell structure and function. Toxicolology In Vitro, Vol. 22, No. 8, (December 2008), pp. 1853-1860, ISSN 0887-2333

Mardon, J., Mathey, J., Kati-Coulibaly, S., Puel, C., Davicco, M.J., Lebecque, P., Horcajada, M.N., \& Coxam, V. (2008). Influence of lifelong soy isoflavones consumption on bone mass in the rat. Experimental Biology and Medicine (Maywood), Vol.233, No.2, (February 2008), pp. 229-237, ISSN 1535-3702

McCue, P., \& Shetty, K. (2004). Health benefits of soy isoflavonoids and strategies for enhancement: a review. Critical Reviews in Food Science and Nutrition, Vol.44, No.5, (2004), pp. 361-367, ISSN 1040-8398

Mensink, R.P., \& Katan, M.B. (1992). Effect of dietary fatty acids on serum lipids and lipoproteins. A meta-analysis of 27 trials. Arteriosclerosis and Thrombosis, Vol.12, No.8, (August 1992), pp. 911-919, ISSN 1049-8834

Mensink, R.P., Zock, P.L., Kester, A.D., \& Katan, M.B. (2003). Effects of dietary fatty acids and carbohydrates on the ratio of serum total to HDL cholesterol and on serum lipids and apolipoproteins: a meta-analysis of 60 controlled trials. Americam Journal of Clinical Nutrition, Vol.77, No.5, (May 2003), pp.1146-1155, ISSN 0002-9165

Messina, M. (1995). Modern applications for an ancient bean: soybeans and the prevention and treatment of chronic disease. Journal of Nutrition, Vol. 125, Suppl.3, (March 1995), pp. 567S-569S, ISSN 1541-3166

Messina, M.J. (1999). Legumes and soybeans: overview of their nutritional profiles and health effects. American Journal of Clinical Nutrition, Vol. 70, No.3, (September 1999), pp. 439-450, ISSN 0002-9165

Mezei, O., Banz, W.J., Steger, R.W., Peluso, M.R., Winters, T.A., \& Shay, N. (2003). Soy isoflavones exert antidiabetic and hypolipidemic effects through the PPAR pathways in obese Zucker rats and murine RAW 264.7 cells. Journal of Nutrition, Vol. 133, No.5, (May 2003), pp. 1238-1243, ISSN 1541-3166

Moser, P.B., Reynolds, R.D., Acharya, S., Howard, M.P., Andon, M.B., \& Lewis, S.A. (1988). Copper, iron, zinc and selenium dietary intake and status of Nepalese lactating women and their breastfed infants. American Journal of Clinical Nutrition, Vol.47, No.4, (April 1988), pp. 729-734, ISSN 0002-9165

Nagarajan, S., Burris, R.L., Stewart, B.W., Wilkerson, J.E., \& Badger, T.M. (2008). Dietary soy protein isolate ameliorates atherosclerotic lesions in apolipoprotein E-deficient mice potentially by inhibiting monocyte chemoattractant protein-1 expression. Journal of Nutrition, Vol.138, No.2, (February 2008), pp. 332-337, ISSN 1541-3166

Nettleton, J.A., \& Katz, R. (2005). n-3 long-chain polyunsaturated fatty acids in type 2 diabetes: a review. Journal of the American Dietetic Association, Vol.105, No.3, (March 2005), pp. 428-440, ISSN 0002-8223

Ni, W., Tsuda, Y., Sakono, M., \& Imaizumi, K. (1998). Dietary soy protein isolate, compared with casein, reduces atherosclerotic lesion area in apolipoprotein E-deficient mice. Journal of Nutrition, 1998;128:1884-1889, ISSN 1541-3166 
Nikander, E., Tiitinen, A., Laitinen, K., Tikkanen, M., \& Ylikorkala, O. (2004). Effects of isolated isoflavonoids on lipids, lipoproteins, insulin sensitivity, and ghrelin in postmenopausal women. Journal of Clinical Endocrinolology and Metabolism, Vol.89, No.7, (July 2004), pp. 3567-3572, ISSN 0021-972X

Nitzke, S., \& Freeland-Graves, J. (2007). Position of the American Dietetic Association. Total diet approach to communicating food and nutrition information. Journal of the American Dietetic Association, Vol.107, No.7, (July 2007), 1224-1232, ISSN 0002-8223

Noriega-López, L., Tovar, A.R., Gonzalez-Granillo, M., Hernández-Pando, R., Escalante, B., Santillán-Doherty, P., \& Torres, N. (2007). Pancreatic insulin secretion in rats fed a soy protein high fat diet depends on the interaction between the amino acid pattern and isoflavones. Journal of Biological Chemistry, Vol.282, No.28, (July 2007), pp. 20657-20666, ISSN 0021-9258

Ologhobo, A.D., \& Fetuga, B.L. (1984). Distribution of phosphorus and phytate in some Nigerian varieties of legumes and some effects of processing. Journal of Food Science, Vol.49, No.1, (January 1984), pp. 199-201, ISSN 1750-3841

Omoni, A.O., \& Aluko, R.E. (2005). Soybean foods and their benefits: potential mechanisms of action. Nutrition Reviews, Vol.63, No.8, (August 2005), pp. 272-283, ISSN 00296643

Orgaard, A., \& Jensen, L. (2008). The effects of soy isoflavones on obesity. Experimental Biology and Medicine (Maywood), Vol.233, No.9, (September 2008), pp. 1066-1080, ISSN 1535-3702

Park, J.H., Jeong, H.J., \& de Lumen, B.O. (2005). Contents and bioactivities of lunasin, Bowman-Birk Inhibitor, and isoflavones in soybean seed. Journal of Agricultural and Food Chemistry, Vol.53, No.20, (October 2005), pp.7686-7690, ISSN 0021-8561

Pase, M.P., Grima, N.A., \& Sarris, J. (2011). The effects of dietary and nutrient interventions on arterial stiffness: a systematic review. American Journal of Clinical Nutrition, Vol.93, No.2, (February 2011), pp.446-454, ISSN 0002-9165

Patisaul, H.B., \& Jefferson, W. (2010). The pros and cons of phytoestrogens. Frontiers in Neuroendocrinology, Vol.31, No.4, (October 2010), pp. 400-419, ISSN 0091-3022

Piekarz, A.V., \& Ward, W.E. (2007) Effect of neonatal exposure to genistein on bone metabolism in mice at adulthood. Pediatric Research, Vol.61, No.1, (January 2007), pp. 48-53, ISSN 0031-3998

Pipe, E.A., Gobert, C.P., Capes, S.E., Darlington, G.A., Lampe, J.W., \& Duncan, A.M. (2009). Soy protein reduces serum LDL cholesterol and the LDL cholesterol:HDL cholesterol and apolipoprotein B:apolipoprotein A-I ratios in adults with type 2 diabetes. Journal of Nutrition, Vol.139, No.9, (September 2009), 1700-1706, ISSN 15413166

Rackis, J.J. (1974). Biological and Physiological Factors in Soybeans. Journal of the American Oil Chemists' Society, Vol. 51, No.1, (January 1974), pp. 161A-170A, ISSN 0003-021X

Rackis, J.J., Wolf, W.J., \& Baker, E.C. (1986). Protease inhibitors in plant foods: content and inactivation. Advances in Experimental Medicine and Biology, Vol.199, (1986), pp. 299347, ISSN 0065-2598

Reynolds, K., Chin, A., Lees, K.A., Nguyen, A., Bujnowski, D., \& He, J. (2006). A MetaAnalysis of the Effect of Soybean Protein Supplementation on Serum Lipids. American Journal of Cardiolology, Vol.98, No.5, (September 2006), pp.633-640, ISSN 0002-9149

Ronis, M.J., Chen, Y., Badeaux, J., \& Badger, T.M. (2009). Dietary soy protein isolate attenuates metabolic syndrome in rats via effects on PPAR, LXR, and SREBP 
signaling. Journal of Nutrition, Vol.139, No.8, (August 2009), pp.1431-1438, ISSN 1541-3166

Rudel, L.L., Parks, J.S., \& Sawyer, J.K. (1995). Compared with dietary monounsaturated and saturated fat, polyunsaturated fat protects African green monkeys from coronary artery atherosclerosis. Arteriosclerosis Thrombosis Vascular Biology, Vol.15, No.12, (December 1995), pp. 2101-2110, ISSN 1079-5642

Sacks, F.M., Lichtenstein, A., Van Horn, L., Harris, W., Kris-Etherton, P., \& Winston, M. (2006b). Soy protein, isoflavones, and cardiovascular health: A summary of a statement for professionals from the American Heart Association Nutrition Committee. Arteriosclerosis Thrombosis Vascular Biology, Vol.26, No.8, (August 2006), pp. 1689-1692, ISSN 1079-5642

Sacks, F.M., Lichtenstein, A., Van Horn, L., Harris, W., Kris-Etherton, P., \& Winston, M. (2006a). Soy protein, isoflavones, and cardiovascular health: An American Heart Association Science Advisory for professionals from the Nutrition Committee. Circulation Vol.113, No.7, (February 2006), pp. 1034-1044, ISSN 0009-7322

Sandström, B., Almgren, A., Kivistö, B., \& Cederblad, A. (1989). Effect of protein level and protein source on zinc absorption in humans. Journal of Nutrition Vol.119, No.1, (January 1989), pp. 48-53, ISSN 1541-3166

Sarkar, F.H., \& Li, Y. (2003). Soy isoflavones and cancer prevention. Cancer Investigation, Vol.21, No.5, (January 2003), pp.744-757, ISSN 0735-7907

Scheppach, W., Luethrs, H., Melcher, R., Gostner, A., Schauber, J., Kudlich, T., Weiler, F., \& Menzel, T. (2004). Antiinflammatory and anticarcinogenic effects of dietary fibre. Clinical Nutrition Supplements, Vol. 1, No.2, (2004), pp. 51-58, ISSN 0261-5614

Sena, C.M., Nunes, E., Louro, T., Proença, T., Fernandes, R., Boarder, M.R., \& Seiça, R.M. (2008a). Effects of alpha-lipoic acid on endothelial function in aged diabetic and high-fat fed rats. British Journal of Pharmacology, Vol, 153, No.5, (March 2008), pp. 894-906, ISSN 0007-1188

Sena, C.M., Proença, T., Nunes, E., Santos, M.S., \& Seiça, R.M. (2008b). The effect of soybean oil on glycaemic control in Goto-kakizaki rats, an animal model of type 2 diabetes. Medicinal Chemistry, Vol.4, No.3, (May 2008), pp. 293-297, ISSN 1573-4064

Setchell, K.D. (1998). Phytoestrogens: the biochemistry, physiology, and implications for human health of soy isoflavones. Americam Journal Clinical Nutrition, Vol. 68, Suppl.6, (December 1998), pp. 1333S-1346S, ISSN 0002-9165

Setchell, K.D., \& Cole, S.J. (2003). Variations in isoflavone levels in soy foods and soy protein isolates and issues related to isoflavone databases and food labeling. Journal of Agricultural and Food Chemistry, Vol.51, No.14, (July 2003), pp. 4146-4155, ISSN 0021-8561

Setchell, K.D., Gosselin, S.J., Welsh, M.B., Johnston, J.O., Balistreri, W.F., Kramer, L.W., Dresser, B.L., \& Tarr, M.J. (1987). Dietary oestrogens - a probable cause of infertility and liver disease in captive cheetahs. Gastroenterology, Vol.93, No.2, (August 1987), pp. 225-233, ISSN 0016-5085

Setchell, K.D., Zimmer-Nechemias, L., Cai, J., \& Heubi, J.E. (1997). Exposure of infants to phyto-oestrogens from soy-based infant formula. Lancet, Vol 350, No.9070, (July 1997),pp. 23-27, ISSN 0140-6736

Shu, X.O., Zheng, Y., Cai, H., Gu, K., Chen, Z., Zheng, W., \& Lu, W. (2009). Soy food intake and breast cancer survival. The Journal of the American Medical Association, Vol.302, No.22, (December 2009), pp. 2437-2443, ISSN 0087-7484

$\mathrm{Si}, \mathrm{H} .$, \& Liu, D. (2008). Genistein, a soy phytoestrogen, upregulates the expression of human endothelial nitric oxide synthase and lowers blood pressure in spontaneously 
hypertensive rats. Journal of Nutrition, Vol.138, No.2, (February 2008), pp. 297-304, ISSN 1541-3166

Sites, C.K., Cooper, B.C., Toth, M.J., Gastaldelli, A., Arabshahi, A., \& Barnes, S. (2007). Effect of a daily supplement of soy protein on body composition and insulin secretion in postmenopausal women. Fertility and Sterility, Vol.88, No.6, (December 2007), pp. 1609-1617, ISSN 0015-0282

Squadrito, F., Altavilla, D., Crisafulli, A., Saitta, A., Cucinotta, D., Morabito, N., D'Anna, R., Corrado, F., Ruggeri, P., Frisina, N., \& Squadrito, G. (2003). Effect of genistein on endothelial function in postmenopausal women: A randomized, double-blind, controlled study. The Americam Journal of Medicine, Vol.114, No.6, (April 2003), pp. 470-476, ISSN 0002-9343

Stocker, R., \& Keaney, J.F., Jr. (2004). Role of oxidative modifications in atherosclerosis. Physiological Reviews, Vol.84, No.4, (October 2004), pp. 1381-1478, ISSN 0031-9333

Symolon, H., Schmelz, E., Dillehay, D., \& Merrill, A. (2004). Dietary soy sphingolipids suppress tumorigenesis and gene expression in 1,2-dimethylhydrazine-treated CF1 mice and ApcMin/+ mice. Journal of Nutrition, Vol.134, No.5, (May 2004), pp. 11571161, ISSN 1541-3166

Takeda, A., \& Tamano, H. (2009). Insight into zinc signaling from dietary zinc deficiency. Brain Research Reviews, Vol.62, No.1, (December 2009), pp. 33-44, ISSN 0165-0173

Trujillo, J., Ramírez, V., Pérez, J., Torre-Villalvazo, I., Torres, N., Tovar, A.R., Muñoz, R.M., Uribe, N., Gamba, G., \& Bobadilla, N.A. (2005). Renal protection by a soy diet in obese Zucker rats is associated with restoration of nitric oxide generation. American Journal of Physiology. Renal Physiology, Vol.288, No.1, (January 2005), pp. F108-F116, ISSN 0363-6127

USDA National Nutrient Database for Standard Reference. Release 23. Nutrient Data Laboratory home page, USDA, Agricultural Research Service; 2010 [cited 2011 Mar 25]. Available from: http://www.ars.usda. gov/ba/bhnrc/ndl.

Velasquez, M.T., \& Bhathena, S.J. (2007). Role of dietary soy protein in obesity. International Journal of Medical Sciences, Vol.4, No.2, (February 2007), pp. 72-82, ISSN 1449-1907

Villa, P., Costantini, B., Suriano, R., Perri, C., Macri, F., Ricciardi, L., Panunzi, S., \& Lanzone, A. (2009). The differential effect of the phytoestrogen genistein on cardiovascular risk factors in postmenopausal women: relationship with the metabolic status. The Journal of Clinical Endocrinology and Metabolism, Vol.94, No.2, (February 2009), pp. 552-558, ISSN 0021-972X

Wallace, G.M., Bannaryne, W.R., Khaleque, A. (1971a). Studies on the processing and properties of soymilk: II. - Effect of processing conditions on the trypsin inhibitor activity and the digestibility in vitro of proteins in various soy milk preparations. Journal of the Science of Food and Agriculture, Vol.22, No.10, (October 1971), pp. 526531, ISSN 1097-0010

Wallace, G.M., Bannaryne, W.R., Khaleque, A. (1971b). Studies on the processing and properties of soymilk: III.-Factors affecting concentration of soymilk and its stability during heat sterilisation. Journal of the Science of Food and Agriculture, Vol.22, No.10, (October 1971), pp. 531-535, ISSN 1097-0010

Weggemans, R.M., \& Trautwein, E.A. (2003). Relation between soy-associated isoflavones and LDL and HDL cholesterol concentrations in humans: a meta-analysis. European Journal of Clinical Nutrition, Vol.57, No.8, (August 2003), pp.940-946, ISSN 09543007 
Weichenthal, S., Moase, C., \& Chan, P. (2010). A review of pesticide exposure and cancer incidence in the Agricultural Health Study cohort. Environmental Health Perspectives, Vol.118, No.8, (August 2010), pp. 1117-1125, ISSN 0091-6765

Williamson, G., \& Manach, C. (2005). Bioavailability and bioefficacy of polyphenols in humans. II. Review of 93 intervention studies. American Journal of Clinical Nutrition, Vol.81, Suppl.1, (January 2005), pp. 243S-255S, ISSN 0002-9165

Wu, A.H., Wan, P., Hankin, J., Tseng, C.C., Yu, M.C., \& Pike, M.C. (2002). Adolescent and adult soy intake and risk of breast cancer in Asian-Americans. Carcinogenesis, Vol.23, No.9, (September 2002), pp. 1491-1496, ISSN 0143-3334

Wu, A.H., Ziegler, R.G., Nomura, A.M., West, D.W., Kolonel, L.N., Horn-Ross, P.L., Hoover, R.N., \& Pike, M.C. (1998). Soy intake and risk of breast cancer in Asians and Asian Americans. Americam Journal Clinical Nutrition, Vol.68, Suppl.6, (December 1998), pp. 1437S-1443S, ISSN 0002-9165

Xiao, C.W. (2008). Health effects of soy protein and isoflavones in humans. Journal of Nutrition, Vol.138, No.6, (June 2008), pp. 1244S-1249S, ISSN 1541-3166

Yamamoto, S., Sobue, T., Kobayashi, M., Sasaki, S., \& Tsugane, S. (2003). Soy, isoflavones, and breast cancer risk in Japan. Journal of the National Cancer Institute, Vol.95, No.12, (June 2003), pp. 906-913, ISSN 0027-8874

Yellayi, S., Naaz, A., Szewczykowski, M.A., Sato, T., Woods, J.A., Chang, J., Segre, M., Allred, C.D., Helferich, W.G., \& Cooke, P.S. (2002). The phytoestrogen genistein induces thymic and immune changes: a human health concern? Proceedings of the National Academy of Sciences of the United States of America, Vol.99, No.11, (May 2002), pp. 7616-7621, ISSN 0027-8424

Young, V.R. (1991). Soy protein in relation to human protein and amino acid nutrition. Journal of the American Dietetic Association, Vol.91, No.7, (July 1991), pp. 828-835, ISSN 0002-8223

Zhan, S., \& Ho, S.C. (2005). Meta-analysis of the effects of soy protein containing isoflavones on the lipid profile. Americam Journal Clinical Nutrition, Vol.81, No.2, (February 2005), pp.397-408, ISSN 0002-9165

Zhang, Y, Chen, W.F., Lai, W.P., \& Wong, M.S. (2008). Soy isoflavones and their bone protective effects. Inflammopharmacology, Vol.16, No.5, (October 2008), pp. 213-215, ISSN 0925-4692 


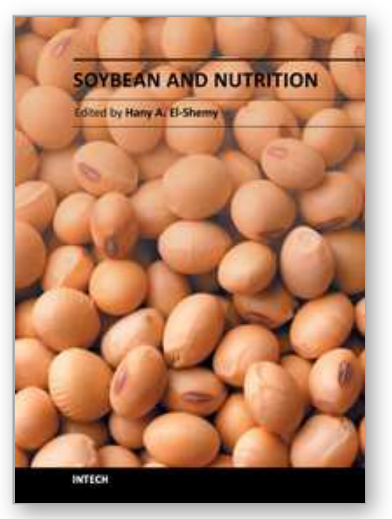

\author{
Soybean and Nutrition \\ Edited by Prof. Hany El-Shemy
}

ISBN 978-953-307-536-5

Hard cover, 476 pages

Publisher InTech

Published online 12, September, 2011

Published in print edition September, 2011

Worldwide, soybean seed proteins represent a major source of amino acids for human and animal nutrition. Soybean seeds are an important and economical source of protein in the diet of many developed and developing countries. Soy is a complete protein and soy-foods are rich in vitamins and minerals. Soybean protein provides all the essential amino acids in the amounts needed for human health. Recent research suggests that soy may also lower risk of prostate, colon and breast cancers as well as osteoporosis and other bone health problems and alleviate hot flashes associated with menopause. This volume is expected to be useful for student, researchers and public who are interested in soybean.

\title{
How to reference
}

In order to correctly reference this scholarly work, feel free to copy and paste the following:

Cristina M. Sena and Raquel M. Seiça (2011). Soybean: Friend or Foe, Soybean and Nutrition, Prof. Hany ElShemy (Ed.), ISBN: 978-953-307-536-5, InTech, Available from: http://www.intechopen.com/books/soybeanand-nutrition/soybean-friend-or-foe

\section{INTECH}

open science / open minds

\section{InTech Europe}

University Campus STeP Ri

Slavka Krautzeka 83/A

51000 Rijeka, Croatia

Phone: +385 (51) 770447

Fax: +385 (51) 686166

www.intechopen.com

\section{InTech China}

Unit 405, Office Block, Hotel Equatorial Shanghai

No.65, Yan An Road (West), Shanghai, 200040, China

中国上海市延安西路65号上海国际贵都大饭店办公楼405单元

Phone: +86-21-62489820

Fax: +86-21-62489821 
(C) 2011 The Author(s). Licensee IntechOpen. This chapter is distributed under the terms of the Creative Commons Attribution-NonCommercialShareAlike-3.0 License, which permits use, distribution and reproduction for non-commercial purposes, provided the original is properly cited and derivative works building on this content are distributed under the same license. 